\title{
Students' Preferences and Their Needs of Reading in Writing Class
}

\author{
Yenni Rozimela ${ }^{1, *}$ Desvalini Anwar ${ }^{1}$ Ririn Ovilia ${ }^{1}$ Ainul Addinna ${ }^{1}$ \\ ${ }^{1}$ English Department, FBS Universitas Negeri Padang, Padang, Sumatra Barat 25131, Indonesia \\ *Corresponding author. Email: yennirozi@gmail.com
}

\begin{abstract}
Many studies have claimed that one's ability in writing is affected significantly by his or her interest in reading. This means that the more one reads, the better one can usually write. Despite its importance, reading activities in class, however, are not yet implemented in ways that can facilitate and help students find ideas more easily and write well. Hence, this study is aimed at finding out the students' perception and preferences about their writing need. A questionnaire was distributed to 137 sophomore students in a university in Padang. The questionnaire is mainly concerned with activities in pre-writing, whilst-writing and post-writing stages. Data analysis reveals that $98.5 \%$ students agree that they need to do some pre-reading to get more information about the topic they will write. In whilst-writing stage, the data shows that the students strongly prefer collaborative writing to individual writing. Lastly, it is no doubt that feedback from both peers and teachers are considered advantageous; yet, direct corrective feedback from teachers is more preferred by more than $70 \%$ students. These results hopefully give insights into how appropriate method and strategy should be implemented in teaching writing.
\end{abstract}

\section{Keywords: Reading-based Writing, Writing Skill}

\section{INTRODUCTION}

Writing has been known as a demanding skill, especially for EFL learners. Students' little exposure to productive writing activities during school has contributed in causing their unfamiliarity with the rhetorical organization and language use applied in written language As a result, students often feel uneasy when they are assigned to write. Therefore, for more than a half century, linguists, educators, and L2 practitioners have been in search for the most suitable approach to teach writing starting from product-based approach, process-based approach and genre based approach.

First is Product-Based Approach which emanates from Behaviorism theory. [1] which sees writing as the result of imitation of the model text ; thus, creativity is not needed in this approach. Therefore, this approach received much criticism. The second approach is Process-Based Approach which is predominantly concerned about the process in writing but not the linguistics aspects [2]. The weakness of this approach is the neglect of the writing product since the focus is much more on the process that the students have gone through starting from pre-writing until revising. The last approach which is currently mostly used is GenreBased Approach. According to Hyland [3], when texts shows similarity in discourse features, it will be easily identified by the students. This approach answers the criticism received by two previous approaches. Genrebased approach provides wider variety of texts which also stresses on the outcome of writing process. In this approach, there are several classification of genres or also known as "Magnificent seven by Sidaway" [4], which can be developed into paragraph, essay and article. Those genres are recount, narrative, explanation, report, procedure, discussion and exposition.

Genre-based approach has undoubtedly been successful in improving both the students' writing ability and the quality of their writing. Kongpecht [5] did an ethnographic case study about genre-based approach in teaching writing to Thai students. The data were collected through students' writings, their diaries about their perceptions of GenreBased and informal interview at the end of semester. The results showed that most students found genre based approach beneficial in teaching exposition text; yet, their opinions on the most useful stage among BKOF, MOT, JCOT and ICOT in students' writing development varied. Thirty eight out of forty-two students or participants chose independent construction as the most useful stage of genrebased approach.

Nordin \& Mohammad [6] reviewed two approaches; process and genre-based and made the best of both approaches. Input was believed to be one of the main factors to consider. Nordin and Mohammad [6] added that the students who possess little knowledge of the rhetorical organization and language use need a great amount of reading activity as the input to write.

Furthermore, according to Krashen [7], students learn how to write by reading (language input). It implies that the 
lesser the input the students get, the more difficult the writing task will be for them. Through reading enforcement, the students can expand their vocabulary, apply complex grammatical construction and write various genres of text. Despite the importance of reading enforcement, EFL learners in Indonesia, for example, have low reading habit and interest. A survey on 130 pre service teachers' reading habit conducted by Aisah, et al [8] showed that the teachers' reading habit was poor .

The difficulties to develop ideas and adapt to certain writing style in writing are the reasons why reading-based writing is needed. This approach promotes students engagement with reading activities in order to provide background information about the topic and adapt to various writing styles.

\section{REVIEW OF RELATED LITERATURE}

Writing ability has been long connected with the amount of reading that the students read. For many years, researchers and language educators have attempted to reveal the good impact of reading on one's ability to write. . As a matter of fact, reading has a prominent role in acquiring a language, not only in writing, but in all aspects of language, as it is proposed by Krashen in his foremost Input hypothesis theory, which later known as comprehension hypothesis. Krashen [8] precisely states, "we acquire language in only one way: when we understand messages; that is, when we obtain comprehensible input." This implies that when one wants to acquire a language, $s($ he) needs massive input which is comprehensible. One of the input sources is from reading materials.

Furthermore, the anecdotal evidence strengthens the role of reading in cramming for improvement of language skills. Narratives told by Renandya [9] elaborated the process of how he mastered English in the first place. In his journey, he highlighted the role of extensive reading in enabling him to move from zero English skills to high proficiency in all language skills including grammar. He mentioned that he even had higher score on grammar test than the students who had practiced grammar more intensivelt than him. At that time, what he did was just reading whatever he found interesting.

Mason [10] did narrative study in which he observed a middle-aged man, Mr Tanaka. Mr Tanaka had not done pleasure reading for 20 yearsand he began to read again. After hearing some explanations about the benefits of pleasure reading on language development, he was interested to join. Within two years, he has read over 10.000 pages and kept the archive of what he had read. Then, he took TOEIC test twice: six months after he started and one year after the first test. His scores were 475 and 655 respectively. Based on the score, the improvement of his language development was significant.

A firm relationship between the amount of reading and students' writing quality has been reported in literature and research reports. It is attested that reading contributes on students' writing development and some aspects of writing (Lee and Hsu, [11]; Kirin, [12]; Mermelstein, [13]; Sakurai, [14] Atayeva, et al, [15]). Lee and Hsu [11] carried out an experimental study investigating the effect of Extensive Reading (ER) on students' writing ability. Extensive Reading (ER), the opposite of Intensive Reading (reading practice done in the class), is a reading activity with purpose of enjoyment. ER, also known as pleasure reading, gives the students privilege to choose the books that they are fond of. This kind reading is not followed by any task or test. 86 third-year vocational college students in Taiwan participated in this study. Compared to other college students in Taiwan, these participants were considered less successful. The treatment in experimental group was that the students did self-selected reading for 50 minutes in each period. Moreover, fluency, content, organization, vocabulary, language use and mechanics were aspects being assessed. The result reported that ER practice made significant difference in all aspects.

A similar study was done by Mermelstein [13]. The main differences between this study and Lee's and Hsu's were on the time spent on reading and the number of participants involved in this study. As many as 221 undergraduate students in Taiwan participated in this study. For the treatments, students in experimental group did sustainedsilent reading for 15-20 minutes in classroom and then they continued doing reading outside the class, at least 3 pages of reading text. The subscales assessed, however, were similar: fluency, content, organization, vocabulary, language use and mechanics. The result showed significant improvement on 5 subscales excluding organization. Another experimental study was conducted by Kirin [12]. The participants were Thai EFL learners who had low motivation in reading. They did ER practice for 15 weeks in which their writings were assessed every five weeks. The result showed affirmative impacts of reading on writing. In reference to these experimental studies, it is no doubt to say that the more the students read and the more they are exposed to language input, the better the writing will be.

Additionally, empirical evidence has also attested the unbreakable relationship between the amount of reading and students' writing ability. Sakurai [14] conducted correlational study finding out the correlation of extensive reading and students' writing performance. 157 first and second-year students at a private university participated in this study. They were non-English students in which some of them had not been involved in ER activity. The results reported the strong correlation of the amount of reading and writing performance. Statically, students who had read in the great amount showed better writing performance, especially on vocabulary and grammar aspects.

Moreover, Atayeva, Setyo, Kassymova, \& Kosbay [15] did the similar work to Sakurai's. They set out a study aiming to find out the relationship of students' reading habit and their academic writing's ability. This study limited to assess students' academic writing as fifty two participants participating in study were graduate students majoring English in Universitas Ahmad Dahlan. This correlational study has proven that students' reading habit undoubtedly contributed on students' academic writing ability.

The relationship between reading and writing is unquestionable. Reading contributes a lot to writing. However, whether students are aware of this relationship 
and their need of reading in writing are needed to find out. This study aimed to investigate the students' preferences in writing class which then lead to their perception of their need of reading in writing class.

\section{METHODS}

The population of this study is the students of Essay writing course academic year 2020/2021. The data were attained through a questionnaire. A questionnaire was distributed to 137 sophomore students. The questionnaire is mainly concerned with students' perception on their writing ability, their preferences based on their needs in pre-writing, whilstwriting and post-writing stages. Based on the result of their preferences, an open-ended questionnaire about their need of reading in writing class was distributed.

\section{RESULT AND DISCUSSION \\ Result \\ Students' perception on their Writing Ability}

The data of students' ability in understanding several genres such as Descriptive, Narrative, Report, Exposition and Discussion texts are elaborated in this section. First, in terms of development ideas, based on their perception, more than $50 \%$ students were in proficient level, and the rests were less proficient. The detail information is presented in following table 1 .

\begin{tabular}{|c|c|c|c|c|c|c|}
\hline \multirow[t]{2}{*}{$N_{0}$} & \multirow{2}{*}{\multicolumn{2}{|c|}{ Aspect }} & \multicolumn{4}{|c|}{ Percentage of students' ability (\%) } \\
\hline & & & \multirow{2}{*}{$\begin{array}{l}\text { Highly proficient } \\
0.7\end{array}$} & \multirow{2}{*}{$\begin{array}{l}\text { Proficint } \\
52.6\end{array}$} & \multirow{2}{*}{\begin{tabular}{|l|}
$\begin{array}{l}\text { Lens } \\
\text { proficieat }\end{array}$ \\
46.7 \\
\end{tabular}} & \multirow{2}{*}{$\begin{array}{l}\begin{array}{l}\text { Not } \\
\text { proficien }\end{array} \\
0\end{array}$} \\
\hline & Idea & Development of ideas & & & & \\
\hline & & $\begin{array}{l}\text { Arrangement } \\
\text { the idea in } \\
\text { order }\end{array}$ & 0.7 & 54.7 & 43.8 & 0.7 \\
\hline
\end{tabular}

In addition, in assessing the students' knowledge and ability on several genres, there were several aspects asked such as the knowledge of social function, generic structure, linguistics features and some additional unique characteristics of each genre. In writing a narrative text, more than $80 \%$ students had knowledge about the social function and the generic structure of narrative text. Besides, about $67.8 \%$ of students understood about language features. Moreover, they claimed that they were proficient in creating the setting, character and conflict in a story which showed that they were able to write a narrative text very well. The detail information about students' knowledge and ability in writing a narrative text is presented in the following table
Table 2. Students' knowledge and ability in writing Narrative text.

\begin{tabular}{|c|c|c|c|c|c|c|}
\hline \multirow[b]{2}{*}{$\mathrm{N}_{0}$} & \multirow{2}{*}{\multicolumn{2}{|c|}{ Aspect }} & \multicolumn{4}{|c|}{ Percentage of students' ability (\%) } \\
\hline & & & \multirow{2}{*}{$\begin{array}{c}\begin{array}{c}\text { Highly } \\
\text { proficient }\end{array} \\
21.9\end{array}$} & \multirow{2}{*}{$\begin{array}{c}\text { Proficient } \\
66.4 \\
\end{array}$} & \multirow{2}{*}{$\begin{array}{c}\begin{array}{c}\text { Less } \\
\text { proficient }\end{array} \\
11.7\end{array}$} & \multirow{2}{*}{$\begin{array}{c}\begin{array}{c}\text { Not } \\
\text { proficient }\end{array} \\
0\end{array}$} \\
\hline 2 & Students & Understanding social function & & & & \\
\hline & $\begin{array}{l}\text { knowledge } \\
\text { and ability to }\end{array}$ & $\begin{array}{l}\text { Understanding generic } \\
\text { structure }\end{array}$ & 14.6 & 69.3 & 14.6 & 1.5 \\
\hline & $\begin{array}{l}\text { write } \\
\text { Narrative }\end{array}$ & $\begin{array}{l}\text { Understanding the language } \\
\text { features }\end{array}$ & 5.8 & 62 & 29,9 & 2.2 \\
\hline & text & Creating a setting for the story & 29.2 & 62.8 & 29.2 & 0 \\
\hline & & Creating a conflict & 5.8 & 43.8 & 48.9 & 1.5 \\
\hline & & $\begin{array}{l}\text { Creating the characters in } \\
\text { the story }\end{array}$ & 5.1 & 63.5 & 31.4 & 0 \\
\hline & & Writing the narrative text & 3.6 & 56.9 & 38.7 & 0.7 \\
\hline
\end{tabular}

The second type of text is Exposition text. $75 \%, 67 \%$ and $52 \%$ students understood about social function, generic structure and language feature respectively. Compared the students' understanding in narrative text, their understanding and ability in writing a narrative text was slightly lower. Even though, they had understanding about exposition text, more than $50 \%$ students had problem in writing thesis statement, writing arguments based on thesis statement and elaborating the arguments. However, in the last point about their ability to write the whole text was contradictory in which about $70 \%$ of students were able to write exposition well. The detail information can be seen in table 3.

Table 3. Students' knowledge and ability in witing Exposition text

\begin{tabular}{|c|c|c|c|c|c|c|}
\hline \multirow[t]{2}{*}{$\mathrm{N}_{0}$} & \multirow{2}{*}{\multicolumn{2}{|c|}{ Aspect }} & \multicolumn{4}{|c|}{ Percentage of students' ability $(\%)$} \\
\hline & & & $\begin{array}{l}\text { Highly } \\
\text { proficient }\end{array}$ & Proficient & Less proficient & $\begin{array}{c}\text { Not } \\
\text { proficient }\end{array}$ \\
\hline \multirow[t]{7}{*}{3} & \multirow{7}{*}{$\begin{array}{l}\text { Students } \\
\text { knowledge } \\
\text { and ability to } \\
\text { write } \\
\text { Exposition } \\
\text { text }\end{array}$} & Understanding social function & 13.1 & 64.2 & 21.9 & 0.7 \\
\hline & & Understanding generic structure & 8.8 & 59.9 & 31.4 & 0 \\
\hline & & $\begin{array}{l}\text { Understanding the language } \\
\text { features }\end{array}$ & 5.8 & 46.7 & 46 & 1,5 \\
\hline & & Writing a thesis statement & 2.2 & 31.4 & 62.8 & 3.6 \\
\hline & & $\begin{array}{l}\text { Writing arguments based on } \\
\text { thesis statement }\end{array}$ & 2.2 & 49.5 & 47.4 & 0.7 \\
\hline & & Elaborating arguments & 0.7 & 40.9 & 56.9 & 1.5 \\
\hline & & Writing conclusion and suggestions & 2.9 & 67.2 & 28.5 & 1.5 \\
\hline
\end{tabular}

Next is discussion text, the most complicated type of texts. The number of students who knew about the common features of discussion text was quite high. $80 \%$ students claimed that they understood about the social function of the text. $67 \%$ understood about the generic structure of discussion text and $54.7 \%$ claimed that they had knowledge about the language features. In terms of writing the discussion text, More than $50 \%$ students claimed that they were good in writing the issues and arguments for both sides. However, the students had difficulty in elaborating arguments from both sides. The percentage was quite high $65 \%$. The detail information is shown in table 4 . 
Table 4. Students' knowledge and ability in writing Discussion text.

\begin{tabular}{|c|c|c|c|c|c|c|}
\hline \multirow[t]{2}{*}{$\mathrm{N}_{0}$} & \multirow{2}{*}{\multicolumn{2}{|c|}{ Aspect }} & \multicolumn{4}{|c|}{ Percentage of students' ability (\%) } \\
\hline & & & $\begin{array}{c}\text { Highly } \\
\text { proficient }\end{array}$ & Proficient & Less proficient & $\begin{array}{c}\text { Not } \\
\text { proficient }\end{array}$ \\
\hline \multirow[t]{6}{*}{4} & \multirow{6}{*}{$\begin{array}{l}\text { Sudents } \\
\text { knowledge } \\
\text { and ability to } \\
\text { write } \\
\text { Discussion } \\
\text { text }\end{array}$} & Understanding social function & 13.9 & 67.2 & 19 & 0 \\
\hline & & Understanding generic structure & 5.8 & 61.3 & 32.1 & 0.7 \\
\hline & & Understanding the language features & 3.6 & 51,1 & 44,5 & 0,7 \\
\hline & & $\begin{array}{l}\text { Writing the issue that will be discussed } \\
\text { in a text }\end{array}$ & 1.5 & 56.9 & 40.9 & 0,7 \\
\hline & & Writing the arguments for both sides & 2.9 & 49.6 & 46.7 & 0.7 \\
\hline & & Elaborating each argument. & 0 & 35 & 63.5 & 1.5 \\
\hline
\end{tabular}

The next type of text is Report text. The percentages of students who had knowledge of social function, generic structure, and language feature were $97.1 \%, 91.5 \%$ and $70.8 \%$ respectively. These numbers were the highest among the above-mentioned types of text. Compared to their knowledge, students' ability in writing classification and description was lower, $61.3 \%$ for writing general statements and $74.5 \%$ for writing the descriptions. The result is presented in table 5 .

\section{Table 5. Students' knowledge and ablity in witing Report text.}

\begin{tabular}{|c|c|c|c|c|c|c|}
\hline \multirow[t]{2}{*}{ No } & \multirow{2}{*}{\multicolumn{2}{|c|}{ Aspect }} & \multicolumn{4}{|c|}{ Percentagg of stadents's ability (\%) } \\
\hline & & & $\begin{array}{l}\text { Highly } \\
\text { proficient }\end{array}$ & Proficient & Less proficient & $\begin{array}{c}\text { Not } \\
\text { proficient }\end{array}$ \\
\hline \multirow[t]{5}{*}{5} & \multirow{5}{*}{$\begin{array}{l}\text { Students } \\
\text { knowledergend } \\
\text { ability to mite } \\
\text { Report terst }\end{array}$} & Understanding social function & 23.4 & 73.7 & 29 & 0 \\
\hline & & Understanding generic stucture & 16.8 & 73.7 & 9.5 & 0 \\
\hline & & Understanding the langlage features & 8.8 & 62 & 29.2 & 0 \\
\hline & & Witing general classification & 7.3 & 54 & 38 & 0.7 \\
\hline & & Writing description of a report terst. & 9.5 & 65 & 24.8 & 0.7 \\
\hline
\end{tabular}

The last text is Explanation. The number of students who knew about the common features of discussion text was high. $94.2 \%$ students claimed that they understood about the social function of the text. $82.5 \%$ understood about the generic structure of discussion text and $62.8 \%$ claimed that they had knowledge about the language features. Looking at the result, their knowledge and their ability seemed in line in which the number of students who were able to write the general classification and phenomenon were $70.8 \%$ and $77.9 \%$ respectively. The result is presented in table 6 .

Table 6. Students' knowledge and ability in writing Explanation text

\begin{tabular}{|c|c|c|c|c|c|c|}
\hline \multirow[t]{2}{*}{ No } & \multirow{2}{*}{\multicolumn{2}{|c|}{ Aspect }} & \multicolumn{4}{|c|}{ Percentage of students' ablility (\%) } \\
\hline & & & \multirow{2}{*}{\begin{tabular}{|c|}
$\begin{array}{c}\text { Highly } \\
\text { proficient }\end{array}$ \\
19 \\
\end{tabular}} & \multirow{2}{*}{$\begin{array}{r}\text { Proficient } \\
75.2 \\
\end{array}$} & \multirow{2}{*}{$\begin{array}{c}\text { Less proficient } \\
5.8 \\
\end{array}$} & \multirow{2}{*}{$\begin{array}{c}\begin{array}{c}\text { Not } \\
\text { proficient }\end{array} \\
0\end{array}$} \\
\hline 6. & \multirow{5}{*}{$\begin{array}{l}\text { Students } \\
\text { knowledge and } \\
\text { ability to write } \\
\text { Explanation text }\end{array}$} & Understanding social function & & & & \\
\hline & & Understanding generic structure & 8.8 & 73.7 & 17.5 & 0 \\
\hline & & Understanding the language features & 2.9 & 59.9 & 32.8 & 4.4 \\
\hline & & $\begin{array}{l}\text { Winting general classification in } \\
\text { Explanation text } \\
\end{array}$ & 4.4 & 66.4 & 28.5 & 0,7 \\
\hline & & Elaborating phenomenon & 10.2 & 67.9 & 21.9 & 0 \\
\hline
\end{tabular}

Students' perception on their Writing Needs

At this section, the analysis result of students' need in writing is presented. The students were asked about their preferences in writing activity which divided into three sections, pre-writing, whilst-writing and post writing activity. In Pre-writing, there were some activities that were offered to the students which were providing the model of text, building students prior knowledge, given direct explanation about the structure, social function and language features by the lecturer, analyzing the structure, social function and language features by themselves, given extra time and additional reading material to read. The detail information is presented in the following table.

\begin{tabular}{|c|c|c|c|}
\hline No & & Aspects & $\begin{array}{c}\text { Percentage of } \\
\text { students' preferences } \\
\text { (\%) }\end{array}$ \\
\hline \multirow[t]{5}{*}{1} & \multirow[t]{5}{*}{ Pre-writing } & Providing the model of the text & 98.6 \\
\hline & & $\begin{array}{l}\text { Building students' prior } \\
\text { knowledge }\end{array}$ & 100 \\
\hline & & $\begin{array}{l}\text { Given direct explanation about the } \\
\text { elements of the text by lecturer }\end{array}$ & 97.1 \\
\hline & & $\begin{array}{l}\text { Analyzing the elements of the text } \\
\text { by themselves }\end{array}$ & 51.1 \\
\hline & & $\begin{array}{l}\text { Given extra time and additional } \\
\text { reading material before writing. }\end{array}$ & 98.5 \\
\hline
\end{tabular}

Based on the table, there were some highlighted points to be noted. Most students would be pleased when the teacher provided the model of text $(98.6 \%)$, and built their background knowledge on topic (100\%). Furthermore, they also preferred given direct explanation about the generic structure, social function and language features by the lecturer to finding those elements by themselves. Additionally, 98.5\% students were asking to be given extra time and additional materials in writing.

Table 8. Students' preferences in whilst-writing
\begin{tabular}{|l|l|l|c|}
\hline No & \multicolumn{1}{|c|}{ Aspects } & $\begin{array}{c}\text { Percentage of } \\
\text { students' } \\
\text { preferences (\%) }\end{array}$ \\
\hline 2 & $\begin{array}{l}\text { Whilst- } \\
\text { writing }\end{array}$ & $\begin{array}{l}\text { Noting down information } \\
\text { gotten from reading }\end{array}$ & 73.7 \\
\cline { 3 - 4 } & & $\begin{array}{l}\text { Listing the elaborated ideas } \\
\text { before writing }\end{array}$ & 87.6 \\
\cline { 3 - 4 } & & Drawing Mind-Mapping & 53.3 \\
\cline { 3 - 4 } & & Free-writing & 73.8 \\
\cline { 3 - 4 } & Collaborative Writing & 71.2 \\
\cline { 3 - 4 } & & Individual writing & 45.2 \\
\hline
\end{tabular}

In Whilst-writing, there were some preferences provided in questionnaires such as noting down the information gotten from reading, organizing ideas in form of listing, mind mapping, free writing in which the students write everything and revise later, collaborative writing, and individual writing. Among several ways of organizing ideas, most students preferred listing their elaborated ideas in form of bullet $(87.6 \%)$ to drawing mind mapping $(53.3 \%) .73 .7 \%$ students who read before writing and would like to note down some important information. Furthermore, between collaborative and individual writing, 
students would to write collaboratively with peers rather than write individually due to some reasons.

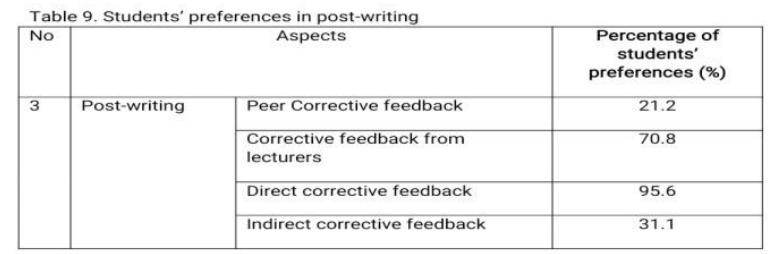

In post writing activities, all students agreed on the importance of feedback from both lecturers and peers. Compared to feedback from peers, most students preferred the feedback from lecturers, $84.6 \%$. To be precise, they preferred direct corrective feedback $(95.5 \%)$ to indirect corrective feedback $(31.1 \%)$.

\section{Students' need of reading in writing class}

Based on the result of students' perception on their writing ability, more than $50 \%$ students acknowledged that they had difficulty in developing ideas, and based on students' perception on their writing needs. It is revealed that more than $90 \%$ students agreed that they needed additional reading materials and additional time to find useful information related to the topic being written. Therefore, open-ended question was distributed to dig deeper on their thought about reading in writing class.

Based on the respondents' answers, it can be concluded that $70 \%$ students liked to write; however, the percentage of students who liked to write in English was 45\%. The decrease of percentage was caused by several factors; vocabulary problem, grammar, and ideas development. Almost all students had difficulty in selecting the vocabulary due to the limit of their vocabulary knowledge in English. In terms of grammar, they had adjusting with the changing tenses due to the changing time. This happened because in their mother tongue language these rules do not exist. These changings made them confused.

Regarding to the students' need on reading in writing class, most students agreed that reading before writing was really important. They realized that when they read sometimes, their writing would be much better in terms of ideas development, vocabulary and the flows of ideas. When the students read before writing, they would not spend much time to think about what they were going to write since they had ideas in their mind. Regarding the vocabulary, they had been familiar with the technical terms in particular topics and it shortened their time in writing. Besides, since they had a lot of information about the topic, their writing flow would be smoother. However, in terms of grammar, they were able to adjust to the English rules. In conclusion, students are in need of reading in writing class due to the difficulties they encountered when writing and they are willing to find relevant sources and read the sources.

\section{Discussion}

Based on the result of students' ability, more than $50 \%$ of the students experienced problem in ideas development. This result is in line with the studies carried out in EFL context [16]. Furthermore, regarding the pre-writing activities, the students demand the model of text as the references when they write. Besides, the background knowledge of students must be built. This is in line with steps implemented in Genre Based Approach, BKOF and MOT [4]. As a result, the students' preferences are accordance with the theory of teaching writing; thus, these activities become a must.

Looking at the results of students' preferences, it is seen that these students are more likely dependent students. They still depend much upon the teachers. For example, instead of analyzing the text by themselves to find the features of the text, they preferred to be given explanation by lecturers. They also chose direct corrective feedback from the lecturer who would highlight all the mistakes and correct them. This is in line with the result of study conducted by Tom et al [17] which was based on students' preferences. The second most useful feedback given by the teacher was highlighting all the mistakes after giving suggestion. In this shifting era from teacher-center to students-center, the students' activeness and teachers' instruction must be balance. In other words, the students too, need to be trained to have analysis skills. Therefore, reading comes as one of the solutions one must apply to answer the challenges found around accomplishing writing tasks.

To enable them to write, the students saw the importance of reading before writing due to the fact that reading can help them to elaborate ideas. Students' need of reading in writing class has been accordance with the existing theory of second language acquisition by Krashen [8]. In this theory, reading is not only useful in writing but also in all aspects of language mastery. In writing especially, reading has contributed a lot which is proven by the empirical evidences given by a numerous researchers and scholars $[11,12,13$, $14,15,16]$. Anecdotal evidences $[9,10]$ have also showed that reading is inseparable with writing and other language skills. Due to the significance role of reading in writing class, it is implicated that there must an approach or method to integrate reading in writing class not as additional part but as for important part of teaching writing.

\section{CONCLUSION}

Overall, based on students' preferences, there were some activities which should be included in pre, whilst and post writing activities. These results can be considerations for teachers to develop material, chose strategy and develop an approach. However, not all the students' preferences can be taken into account; it depends on what is needed by the students based on the lecturers' perception and existing theory. Furthermore, most important point found in this study is that the students' acknowledgement of the vital role of reading in writing class which is also accordance with the theories. Thus, this result becomes the bases for developing an approach which integrates reading into writing.

\section{ACKNOWLEDGMENTS}

The researchers would like to thank the people who helped in and contributed to the research. First, the researchers would like to thank LP2M UNP who has provided financial 
support distributed as PNBP 2020 scheme in conducting the research. Finally, the appreciation goes to the research assistants, the English Department students, especially those who took Essay Writing course in 2020/2021 academic year who have participated actively during the research.

\section{REFERENCES}

[1] Badger, R \& Goodith, W. 2000. A Process Genre Approach to Teaching Writing. ELT Journal, 54 (2). 153 160.

[2] Hasan, M.K., \& Akhand, M.M. 2010. Approaches to Writing in EFL/ESL Context: Balancing Product and Process in Writing Class at Tertiary Level. Journal of NELTA, 15(1): 77-88

[3] Hyland, K. 2007. 'Genre pedagogy: language, literacy and L2 writing instruction'. Journal of Second Language Writing 16/3: 148-64.

[4] Sidaway, R. 2006. 'The genre-based approach to teach writing'. In English! Spring issue: 24-7.

[5] Kongpecth, S. 2006. Using a genre-based approach to teach writing to Thai students; A case study. Prospect, 21 (2): 3-33.

[6] Nordin, S.M., \& Mohammad, N.B. The best of two approaches: Process/ genre based approach to teaching writing. The English Teacher. 75, 75-85.

[7] Krashen, S. 2016. Compelling reading and problemsolving: The easy way (and the only way) to high levels of language, literacy, and life competence. In Epoch making in English language teaching and learning. Twenty-fifth international symposium on English teaching (pp. 115 125).

[8] Aisah, S., El-sulukiyyah, A.A., \& Aisyah, R.N. 2019. Survey on the reading habit of Indonesian pre-service EFL teachers. Journal of English Language Education. 2/2, 148-171.
[8] Krashen, S. 2003. Exploration in Language Acquisition and Use. Heinamann.USA.

[9] Renandya, W.A. 2007. The power of extensive reading. RELC Journal. 38(2), 133-149.

[10] Mason, B. 2011. Impressive gains on the TOEIC after one year of comprehensible input, with no Output or grammar study. International Journal of Foreign Language Teaching, 7(1).

[11] Lee, S., \& Hsu, Y. 2009. Determining the crucial characteristics of extensive reading programs: The impact of extensive reading on EFL writing. The International Journal of Foreign Language Teaching, 5 (1), 12-20.

[12] Kirin, W. 2010. Effects of Extensive Reading on Students' Writing ability in an EFL Class. The Journal of ASIA TEFL. 7 (1), 285-309.

[13] Mermelstein, A.D. 2015. Improving EFL learners' writing through enhanced extensive reading. Reading in $a$ Foreign Language. 27(2), 182-198.

[14] Sakurai, N. 2017. The Relationship between the amount of extensive reading and the writing performance.

The Reading Matrix: An International Online Journal. 17(2), 142- 164.

[15] Atayeva, M., Setyo, P.N.H.P., Kassymova, G., \& Kosbay, S. 2019. Impact of Reading on Students' Writing Ability. Materials of International Practical Internet Conference "Challenges of Science". ISBN 978-601-323144-0. Issue II, 2019. Page 5-13. https://doi.org/10.31643/2019.001.

[16] Toba, R., Noor, W,N., \& Sanu, L.O. 2019. The current issue of Indonesian EFL students' writing skills: Ability, problem, reason in writing comparison and contrast essay. Dinamika Ilmu, 19 (1), 57-73.

[17] Tom, A.A., Metom, L., Morni, A. \& Joe, S. 2013. Students' perception and preferences of written feedback in academic writing. Mediteranian Journal of Social Science. 4(1), 72-80. 